\title{
Reshaping Institutional Arrangements for the Trade Policies of the US and their Implications for the Asian Region
}

Author(s): Jungsuk Kim, Insoo Pyo, Jacob Wood

Source: Journal of International Logistics and Trade 2018; 16(3):109-119

Published by: Jungseok Research Institute of International Logistics and Trade, Inha University

DOI: https://doi.org/10.24006/jilt.2018.16.3.109

The Journal of International Logistics and Trade is an official journal published by Jungseok Research Institute of International Logistics and Trade, Inha University, Korea. JILT welcomes manuscripts that advance the practice and science of logistics, trade, and other related fields.

Frequency: Quarterly (March, June, September, December)

Stable URL: https://www.ejilt.org

The Jungseok Research Institute of International Logistics and Trade is a specialized academic research institute representing Inha University and the Inha Foundation in Korea. The institute aims to become a representative institute in Northeast Asia in the research of logistics and trade.

Stable URL: https://jrieng.inha.ac.kr

(C) Copyright. Jungseok Research Institute of International Logistics and Trade.

This is an Open-Access article distributed under the terms of the Creative Commons Attribution NonCommercial License (http://creativecommons.org/licenses/by-nc/4.0/) which permits unrestricted noncommercial use, distribution, and reproduction in any medium, provided the original work is properly cited 


\title{
Journal of
}

\section{International Logistics and Trade}

\section{Reshaping Institutional Arrangements for the Trade Policies of the US and their Implications for the Asian Region}

\author{
Jungsuk Kim ${ }^{\mathrm{a}}$, Insoo Pyo ${ }^{\mathrm{b}}$, Jacob Wood ${ }^{\mathrm{c*}}$ \\ ${ }^{\text {a }}$ Department of Economics and Trade, Sejong University, Korea \\ ${ }^{\mathrm{b}}$ Bae, Kim \& Lee, Korea \\ ${ }^{\mathrm{c}}$ Department of Business, James Cook University Singapore, Singapore
}

\begin{abstract}
ARTICLE INFO
Article history:

Received 14 July 2018

Accepted 26 December 2018

Keywords:

US trade policy

International trade

Korea-US FTA

TAA

America first

ABSTRACT

This study analyzes the policy initiatives that have been adopted by the US government since the 1930s. We document the institutional bodies responsible for the implementation of trade policy, as well as the objectives and decision making practices that are associated with policy formation. We also examine the new institutional movement of the Trump Administration's neo-protectionist "America First" trade policy and its potential impact on the Asian region. Finally, our study examines the recent renegotiation of Korea-US FTA from a perspective of each country's internal decision making process and discusses a number of issues that have relevant applications for Korea. The results from our analysis show that U.S trade policy show that despite a long period of an open and liberalized trade policy focus, recent neo-protectionist measures by President Trump could lead to potential trade wars and a return to the beggarthy-neighbor policies of the 1930s. Such an anti-globalization agenda could have dire consequences for export dependent countries in the Asian region.
\end{abstract}

\section{Introduction: An historical overview}

At the turn of 20th Century, the US was an economy on the move. The economy was growing, and liberalized trade policy was the order of the day. However, the Wall Street Crash, and the great depression that followed saw the introduction of more protectionist measures. At the heart of these was the Smoot-Hawley Tariff Act of 1930, which set prohibitively high tariff rates in an attempt to offer protection to producers that were severely affected by the great depression. However, these exacerbated the many economic problems and led to a series of retaliatory tariffs being implemented by major US trade partners (Fergusson, 2015). However, with the election of Franklin D. Roosevelt as US President in 1934, a new era of trade policy was ushered in by way of the Reciprocal Trade Agreement Act (RTAA) of 1934.

Under the RTAA, the President was given the authority to enter into and negotiate reciprocal trade agreements that led to tariff reductions. The Act served as institutional reform which resulted into a reduction in tariff duties and a more liberalized trade policy platform. Following an interjection for World War II, the US continued to embrace open trade policy reform. In this instance, both the US and the UK played an instrumental role in rebuilding the destroyed post-war economic systems of Japan and Europe.

The US was also a key player in shaping the post WWII economic and trade agenda at the Bretton Woods conference in 1944. The outcome of this meeting pathed the way for the formation of the International Monetary Fund (IMF), and the International Bank for Reconstruction and Development (IBRD, now known as the World Bank). While the US led Conference failed in its bid to launch the International Trade Organization (ITO), it was however successful in launching

\footnotetext{
* Corresponding author: Department of Business, James Cook University Singapore, 149 Sims Road, Singapore

Email: jacob.wood@jcu.edu.au
} 
the less ambitious General Agreement on Tariffs and Trade (GATT), which was adopted in its place. The implementation of these globally orientated finance and trade initiatives provided the necessary launching pad that would help to catapult a more liberalized trade policy memorandum in the US and many other countries around the world. In the years following the conclusion of WWII, the American economy prospered. As the world's preeminent political and economic powerhouse, the US dominated large parts of the global trading environment. However, the good times were not destined to last forever.

By the early 1970s, things had begun to change with a real emphasis being placed on the need to drive a liberalized trade agenda. A key success during this time was Robert Strauss's efforts as President Jimmy Carter's Special Trade Representative, to gain congressional approval of the Tokyo Round Agreements, which formed an integral part of GATT's multilateral negotiations at the time and the beginning of an important set of trade liberalizing agreements which would be endorsed by means of an innovative "fast track" process.

By 1988, further change by way of the Omnibus Trade and Competitiveness Act, provided the Bush Administration with a mechanism that allowed the government to categorize nations as being unfair traders based on the number and pervasiveness of their acts, policies, or practices that impede US exports. This was followed by the introduction of the North American Free Trade Agreement (NAFTA) in 1994 and a broad political consensus that the US needed to be more aggressive in promoting commercial interests overseas. As the domestic economy surged and Japan continued to decline, the US found itself in an unexpectedly dominant hegemonic position in the international economy and successful in its bids to complete FTAs with Jordan and Chile ${ }^{1}$. During this time, America also played an important role in establishing not only a new trade preference program with Africa, but also, and perhaps more importantly in helping negotiate and win legislative approval for China's entry into the WTO.

In more recent times, the 2007 US-Peru FTA, signified a change of tack for US trade policy as a range of legislative provisions were implemented that tie FTAs with Multilateral Environmental Agreements (MEAs) and certain labor rights (Schmidt, 2009). Since then, the world economy has gone through the rigors of a global financial crisis, the likes of which hit America hard. While the multilateral Doha Development Agenda Trade Treaty has stalled the US looked to build bilateral or regional FTAs, including the Transatlantic Trade and Investment Partnership (TTIP), and the once US-led Trans-Pacific Partnership (TPP), an agreement that the US has now turned its back on.

Given such an historical context, this study takes a step back from the history to better understand the mechanisms that exist within government that orchestrate trade policy. In this regard, Section 2 details the institutional elements that drive US trade policy formation and the participants in the trade policy decision making process. Section 3 discusses the United States new neo-protectionist agenda and its impact on Asia. Finally, Section 4 draws a series of relevant conclusions, including the role of Brexit in helping change the trade policy landscape, in particular the important role the Korean Korean National Assembly has taken in the formation of trade policy.

\section{Institutional mechanisms of US trade policy}

\subsection{Participants in trade policy decision making}

The trade policy decision-making practices implemented in the US, display a range of unique features, the two most significant of which are the executive and legislative authorities (see Figure 1). Congress, as the legislative body of US politics, has for more than 150 years, exercised authority over foreign trade. Although its House of Representatives are unable to execute policies directly they have played an important role in setting tariff rates on all imported products. The US constitution assigns express authority over the regulation of foreign trade to Congress. Article I, Section 8, gives Congress the power to "regulate commerce with foreign nations" and to "lay and collect taxes, duties, imposts, and excises" (Fergusson, 2015). In this instance, the power that belongs to Congress, is shared between the House of Representatives and the Senate.

Leading the executive element, the president is also a major participant in the trade policy decision making process. As the focal point of the US political system, the President has the authority to make major decisions without any consideration from congress. Under Article II of the US constitution, it states that the President has the exclusive authority to negotiate treaties and international agreements and has wide ranging authority over the way in which the country's foreign affairs are conducted. The introduction of the RTAA in 1934, was also significant for several reasons. Firstly, for the first time, Congress expressly delegated to the President an authority to reduce tariffs with congressionally predefined ranges. In the field of trade, these powers allow the President to make executive orders such as those identified in "Super 301" which can limit trade practices. In particular, President Trump is often viewed as exercising his executive powers by implementing Executive Orders and Presidential Memorandum in many areas including international trade issues. However, from an institutional perspective, this new phenomena in the US seems to be a temporary one rather than a real shift of power from Congress to the President in the way international trade policy is formulated. While executive orders can play an important role in the policy decision making process, trade policy decisions are also shaped by individual

\footnotetext{
${ }^{1}$ The US-Jordan FTA came into force on December 17, 2001 while the US-Chile FTA entered into force on January 1, 2004.
} 
members of congress. These members can affect trade policy first as voting representatives who collectively determine the statutes governing trade matters. In addition to this, governing officials may also have some influence over members that are sitting on relevant committees, in testimony before committees irrespective of whether they are members or not. Finally they may also have informal influence over other members through the political authority invested in them as an elected electorate official. U.S. trade policy is based on statutory authorities, as voted on and passed by Congress and include laws authorizing trade programs as well as policies on tariffs, nontariff barriers, trade remedies, and import and export policies (Cimino-Isaacs, 2018).

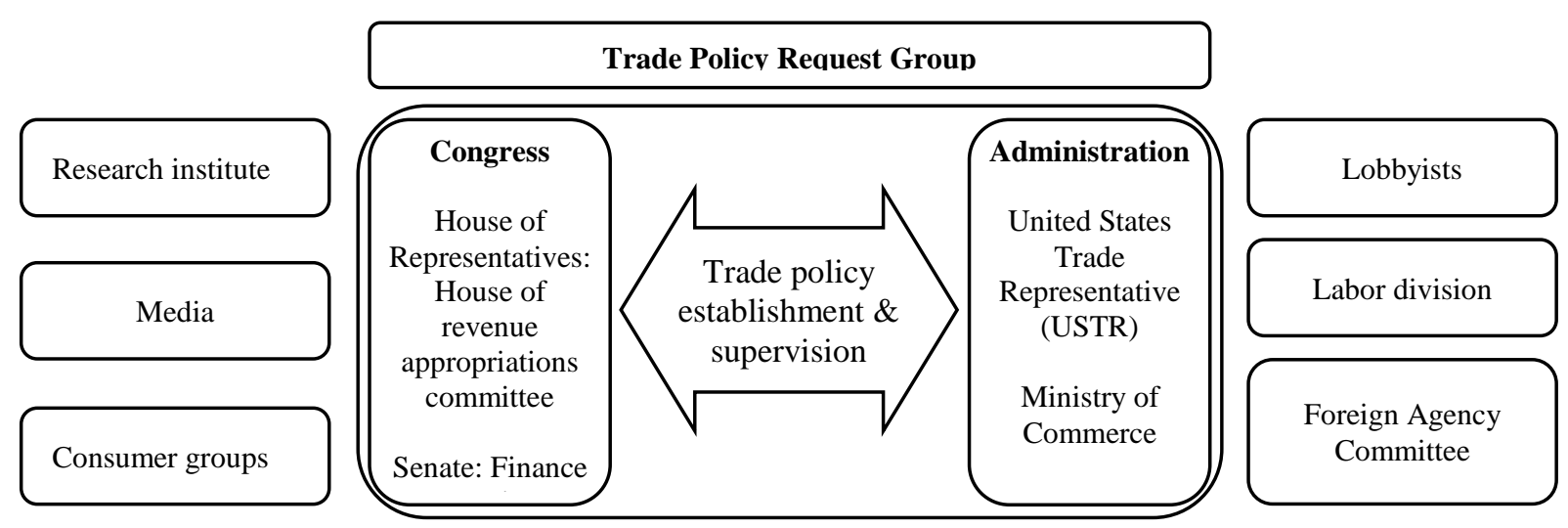

Figure 1. Participants in the US trade policy decision making process. Source: Ko and Choi (2014)

\subsection{Institutional arrangement}

\subsubsection{Congress}

As the legislative authority on foreign trade, the US Congress has been in an influential figure in setting the trade policy agenda (Kim, 2006). Congress consists of two primary bodies. Firstly, a House of Representatives, which is made up of 435 elected officials ${ }^{2}$, which as of 2018, the House has a Republican majority with 236 Republicans, 193 Democrats, with 6 seats currently vacant. And secondly, the Senate, which is composed of 100 people, with 2 persons elected from each of America's 50 states $^{3}$.

Due to the increasingly complex nature of the work, officials from the US House of Representatives and Senate delegate responsibility to several congressional committees. Among the most important to international trade issues are the Revenue Appropriations Committee (RAC) (Ways and Means Committee) in the House of Representatives and the Senate Finance Committee. Both Committees play an integral role in governing tariff and non-tariff barriers related to foreign trade. However, the primary responsibilities of the House RAC can be more specifically documented to include customs regulations, technical standards, dumping or subsidies as well as oversight over unfair trade regulations, import restrictions, bilateral or multilateral trade agreements, trade laws and monitoring agencies that are related to legal trade issues. It is also responsible for the management of federal debt and public funding projects. Another important governing body is the Standing Committee. This particular Committee sets out the House of Representatives agenda and is responsible for operational procedures. In the House of Representatives, there are 20 standing committees that are organized around major policy areas. Each committee is equipped with executive staffing, independent budgetary oversight and relevant subcommittees. These committees can conduct hearings on matters of public interest, undertake research, and put forward legislative proposals for further discussion. The other major committee, as previously identified, is the Senate Finance Committee. This Committee is responsible for the management of federal government debt, customs, public funding, social security and health care funding program, national pension services, reciprocal trade agreements, revenue-related measures, tariff and transportation matters as well as managing import quotas for specifically target items. As the Revenue Appropriations and Finance Committees are the most influential groups in the House and Senate, their respective chairpersons are considered to be the most powerful figures in US trade policy. In order for a law to move smoothly through both the House and the Senate, the proposed bill should be very similar to the one that is discussed by the House of Revenue Appropriations or Senate Finance Committees. If the trade legislation is contrary to the best

2 The House of Representatives is made up of persons elected from the various states. Persons are included according to the proportion of population in an area. The term of office of the House of Representatives is two years, with every congressman having to seek reelection every two years.

${ }^{3}$ In the US Senate, each representative serves as a senator for 6 years with one-third of these officials being up for election every two years. 
interests of the members of Chairpersons of these Committees, then it is likely that the bill will either be substantially modified or disposed of before the plenary session is conducted.

Another important aspect that helps to define Congress, is the way in which its members ultimately endeavor to reflect the nature of the electorate in which they serve. In this instance, representatives are more sensitive to their constituents' views, than the policy direction of the political party they represent or indeed the country as a whole. While representative voting behavior is done according to one's own judgment and conscience, in recent years, the House has borne witness to a decline in "cross-voting" with voting behavior becoming increasingly in line with a respective party's policy manifesto. A segment of any constituency, are the interest groups that may be disenfranchised by a particular trade policy measure. Their voices are heard in the various subcommittees which are formed in Congress. These mechanisms provide an ideal place to gauge the views of both the general public and specific industries. In addition, subcommittees play a vital role in not only reviewing a new piece of legislation they also help to educate and inform lawmakers about the potential ramifications of the new measure.

Apart from the representatives themselves, Congressional aides are also an important facet to workings of the US Congress. Since the 1970 s, their number has been steadily increasing and whilst they have no formal voting rights, their impact on the decision making process cannot be underestimated. Their duties are widespread and while their main function is to oversee and conduct research and administer clerical duties they can also be called upon to provide a crucial advisory role to lawmakers. They can also form an important go between for members that are anxious to know how a particular trade negotiation is going. Outside of the aides there are several other types of Congressional staff, the likes of which can be divided into the following categories: personal staff to assist with specific legislative affairs; committee personal that are employed in the various committees and sub-committees, including the various standing committees; managerial staff that assist both the House Majority Leader and Senate Minority representatives; and institutional staff helping in the General Administration Office, including the Federal Capitol Police, the Congressional Research Service Bureau CRS (Congressional Research service), the Congressional Budget Office CBO (Congressional Budget Office), the Congressional Audit Bureau GAO (Government Accountability Office).

The US Congress controls all issues relating to the reporting and documentation of trade issues. It is also indirectly involved in establishing operational guidelines as well as giving budget allocation approval. Up until the implementation of the RTAA of 1934, Congress had sole control over the setting of tariff levels. In the years following, the President has assumed much of the responsibility. That was until 1962, when the Trade Expansion Act saw an expansion of Congress's role in the negotiating process that required the President to submit for Congressional review a copy of the concluded agreements as well as an associated report that clearly explained why the agreement was necessary. Further legislative changes were made when the Fast Track Negotiating Authority was created as part of the Trade Act of 1974. Under this initiative, the President was again given power to enter into trade agreements that dealt with the reduction and/or removal of import tariffs. However, in addition to this, the act also gave Congress the power to examine non-tariff issues. In this instance, the act stipulated that non-tariff barrier agreements could only come into force if Congress passed the necessary legislation. The law remained in effect for 5 years and was extended for a further two years before expiring in January of 1982. The Trade and Tariff Act of 1984, sought to amend the Trade Act of 1974, by adding trade agreements authority that provided for the "negotiation" and implementation of bilateral free trade agreements that both reduced or eliminated tariffs and addressed nontariff barriers (Fergusson, 2015). Another significant legislative provision, was the Comprehensive Trade Competitiveness Act (Omnibus Trade and Competitiveness Act, 1988) which was designed to help the President negotiate and conclude trade agreements while Congress implemented 'fast-track procedures' so as to review and decide to pass into legislation a potential agreement. The fast track authority was then renewed as part of the Bipartisan Trade Promotion Authority Act (BTPA) of 2002. The fundamental structure of the act was very much the same as previous trade agreements authority. However, it included new labor and environmental aspects which were referred to as principal negotiating objectives. The Act also created a new mechanism for congressional consultation. Titled the Congressional Oversight Group (COG), its main responsibility was to operate in addition to other congressional trade advisors. Under the 2002 TPA, Congress passed a number of significant trade agreements including the FTA deals with Chile, Singapore, Australia, Morocco, The Dominican Republic, the Central American countries, Bahrain, Oman, Peru, Colombia, Panama, and South Korea (Fergusson, 2015).

\subsubsection{Administration}

The executive branch of US trade policy administers trade laws that have been passed by Congress. There are many agencies that play a role within this aspect of trade policy formation. Those that head the various institutions are political appointees nominated by the President and are approved by Congress. Among the most important of these executive agencies for trade policy include the US Trade Representative (USTR), the Department of Commerce; the Department of Agriculture, and Customs and Border Control, while other agencies play critical roles as well (such as the Department of the State, the Department of Treasury, the Department of Homeland Security, the Department of Labor, and the Food and Drug Administration). Despite drawing on a range of institutional areas within government the overall persuasion of the executive branch is towards liberalized free trade. Nonetheless, the administration is also willing to respond to the calls of industry that have been impacted by trade deals and implement not only protectionist measures but also forms of trade 
assistance.

\section{A. USTR}

The leading player in trade policy formation is the US Trade Representative. The USTR has the primary responsibility, with the advice of the interagency trade policy organization, for developing and coordinating the implementation of US trade policy. The USTR plays two vital roles. Firstly, as a mediator and policy coordination between the respective government agencies and interest groups, while the other is to lead various trade negotiations on behalf of the US. As part of its negotiations, the USTR documents proceedings and announces trade barrier specifications and restrictions to market access and looks to establish common ground with its respective foreign counterparts. The USTR has played a major role in the renegotiation process of NAFTA and the US-Korea FTA. The USTR executes its institutional interagency role through two processes the Trade Policy Review Group (TPRG) and the Trade Policy Staff Committee (TPSC), both of which are chaired by the USTR. Both of these groups are overseen by the Office of Policy Coordination. The Office then in turn advises the USTR on how to overcome any potential policy differences that may occur across the different agencies, since all trade policy decisions require consensus. Each year on average, the office negotiates agreement for some 285 policy papers and negotiating documents, and chairs 54 TPSC and TPRG meetings (USTR, 2018). The Office is also responsible for gaining an understanding of public opinion surrounding policy decisions and negotiations by holding public hearings and providing Federal Register notices. Of the reports it creates annually, the National Trade Estimates Report of Foreign Trade Barriers is of particular significance.

\section{B. Department of Commerce}

Established in 1980, under the guidance of the International Trade Administration (ITA), the Department of Commerce (DOC) operates in three divisions and is responsible for the activities and responsibilities of international trade for the non-agricultural sector of the department of Commerce. The Department of Commerce (DOC) plays an important role in the development of trade policy and DOC's role seems to be more important in the Trump Administration due to its heavy reliance on Executive Orders made by the President. As an administration that oversees the management of almost every industry in the US economy, the DOC endeavors to help implement policy initiatives that enhance US competitiveness in global markets. By ensuring US industry has access to state-of-the-art technologies and the types of information businesses need to thrive, the DOC also seeks to provide a domestic platform from which sustainable economic opportunities and job creation is possible and by which strong economic growth is achievable. Although it was initially created as a means of promoting the domestic economy, the DOC has evolved to perform a variety of tasks. Some of these include the exploration and analysis of foreign market opportunities; an analysis of import-related duties, such as anti-dumping and countervailing measures; and an analysis of Trade Agreements and research as to their potential impact on domestic US industries. In particular, the DOC has implemented a new law called the Trade Preferences Extension Act of 2015. According to provisions stipulated within this Act, the DOC has more discretion in investigating anti-dumping cases by adopting both the Adverse Facts Available (AFA) rule and the Particular Market Situations (PMS) rule. By utilizing these rules, it is easier for the DOC to impose high dumping margins for products that are imported from other foreign countries including China. Furthermore, the DOC developed a set of new investigation tools, the socalled Section 232 measures, under which the DOC can impose trade restrictive measures based on the national security purposes. In this instance, President Trump ordered the DOC to investigate steel products from Korea to see whether or not they could threaten US national security. Although President Trump has not ordered any sanctions against Korean steel products yet, this new challenge may bring vigorous opposition from traditional trading partners including those as powerful as the European Union.

\section{Unites States International Trade Commission (USITC)}

Created in 1916 by the Revenue Act, it was first launched as the US Customs Committee, however, with the introduction of the Trade Act of 1974, it was renamed the International Trade Commission (ITC). The ITC is a research institution which also makes legislative assessments about the link between US trade policy and its impact on domestic industry. It also conducts research on international trade issues and makes suggestions to both the President and the US Congress as to the best course of policy direction. As an independent quasi-judicial agency operating under the jurisdiction of the President, the USITC advises the President about the impact of trade agreements and the enforcement of preferential tariff rates on the domestic economy. In conjunction with this, the ITC also monitors trade flows with former communist countries; determines the effect of anti-dumping and countervailing duty measures; monitors the violation of intellectual property rights under the Article 337 of the Customs Act; and investigates other unfair trade practices that US trading partners may be engaged in. 


\section{Other important administrative departments}

US State Department. The US State Department, while promoting homeland security through the development of a successful foreign policy agenda, is actively involved in trade policy issues. It provides feedback to the USTR and assists with the execution of certain policy initiatives. The US State Department plays an important diplomatic role in mitigating and resolving potential areas of conflict that have arisen as a result its often aggressive pursuit of a liberalized open market global trade agenda.

Department of Labor. The Department of Labor is another important administrative arm within the make-up of US trade policy. With a focus on promoting the well-being and security of US workers at home and abroad, the department is also heavily involved in the formulation of international economic policy and trade policy that affects American workers. As the US has reached out and developed trade deals with developing countries, the Department of Labor has worked alongside the International Labor Organization (ILO) to improve labor standards. As such, US trade deals have for some time included a range of labor standards that must be met in order for agreements to move forward.

Treasury Department. The Treasury Department is also actively involved in trade policy making by adjusting monetary policy that is related to trade or foreign domestic investments, and the execution of tariff measures. Starting in 2016, the role of the Treasury Department has increased from an international trade context as it now has the authority to publish a biannual report on the 'Foreign Exchange Policies of Major Trading Partners of the United States'. Based on the Report, the Treasury Department can impose a certain trade remedy when a country is nominated as one that is involved in Currency Manipulation or is on the Monitoring List. The Report is based on the new BHC Act (Bennet-Hatch-Carper Act: Trade Facilitation and Trade Enforcement Act of 2015), which came into effect in February 2016. As foreign exchange rate concerns continue to rise, particular in respect to China, the Treasury Department will become an increasingly important agency in the future. In October 2017, the Treasury Department put five countries (China, Japan, Germany, Switzerland and South Korea) on the "Watch List" of foreign currency manipulating countries.

Lobbyists and industrial associations. Other external groups such as industrial associations and lobbyists are also important. US Trade policy represents a range of viewpoints and as such it is imperative that all aspects of industry are included within the negotiation and decision making processes. From an association perspective, the National Association of Manufactures, the American Petroleum Institute, the American Automotive Policy Council, and the International Intellectual Property Alliance are influential players. In conjunction with their efforts are the workings of large wellorganized lobbyists. These mainly administrative and/or business officials are instrumental in helping shape US trade policy. Their significant financial backing yields tremendous power and influence in Washington with many political election campaigns dependent on lobbyist donations. In exchange for this support, political leaders have for some time implemented trade policy measures that are beneficial to the industries or businesses that these lobbyists represent. No area of government is beyond the reach of these highly capable and well-organized players, with Congress, the Administration, and even the Whitehouse itself being targeted.

\section{United States new neo-protectionist agenda and its impact on Asia}

The US has traditionally used trade policy as an important tool for developing not only its own domestic economy but also strengthening the relationships it enjoys with both its allies and rivals. Until recently, trade has been viewed by a succession of US Presidents as a mechanism for fostering stronger economic ties, preventing conflict between nations, enhancing competition and market participation and strengthening labor and environmental standards. However, in recent times, the US and other significant liberal democracies have sought to step back from their commitment to free trade. In the US, President Trump has implemented an array of neo-protectionist trade measures as part of wider America first policy agenda. In the United Kingdom, the Brexit referendum result indicated their nations desire to retreat from European Market integration (Wood, 2018).

Broadly speaking, this neo-protectionist trade policy reflects US attempts to save domestic jobs, by placing tariffs on imported goods and restricting the flow of foreign workers and people. Nowhere in the world have these anti-trade measures been more apparent than in the US, where the ideals of free trade and globalism ideals have almost become dirty words (Wood, 2018). Since the 2016 US Presidential Election, there have been growing concerns about the type of rhetoric and policy measures being put forward by the Trump Administration. As a long-time advocate for open liberalized trade policy in Asia, the US has sought to implement measures that firmly put America first. A key aspect in this regard, was a decision to walk away from the Trans-Pacific Partnership Agreement (TPPA) in January 2017, a President Obama led comprehensive free-trade deal involving 12 pacific-rim economies. The decision reflected concerns the Trump administration had that the TPPA would be extremely detrimental to American manufacturing. Such decisions by the Trump administration highlight key aspects of its economic and trade policy agenda, such as movements away from trade liberalization through imposing trade restrictions, a focus on bilateral trade deficits and a desire to make 
fundamental change to the WTO (Stiglitz, 2018).

The US government has also been very active in its critical portrayal of China's trade and monetary policies. In particular, the belief that China is a currency manipulator, whereby it systemically devalues its currency to a bid to take unfair advantage of the US and other countries (Wood, 2018). Many members of congress firmly believe that China's exchange rate policy has been a key cause behind significant job losses and the gradual decline in US competitiveness (Ramirez, 2013). From a trade perspective, the key issue has been the rapidly increasing trade surplus that China and many of the US's trading partners enjoy, an issue that is clearly documented in Table 2. The trade deficit of the US with China has expanded from around zero during the 1970s to \$752 billion in 2016 (Lin and Wang, 2018) A key election campaign pledge, President Trump has been keen to make a dent in these perceived imbalances. In March of 2018, the US government ordered trade officials to increase tariffs on some 1,333 Chinese imports, predominantly steel and aluminum products, totaling more than US\$50 billion (USTR, 2018). China in response showed little fear, acting swiftly to impose an equivalent US\$50 billion of tariffs were placed on a range of US imports including soy beans (the US' largest agricultural export to China, worth US\$14 billion annually), automobiles, and aviation sectors amongst others (Wood, 2018). However, not to be outdone, President Trump instructed the Office of the US Trade Representative whether it was appropriate to enact an additional US\$100 billion of tariffs, citing the country's unfair practices of obtaining US intellectual property (ICTSD, 2018a). From the US's perspective the goals of such measures are to reduce the US-China trade imbalances and to retain jobs in the US (Lin and Wang, 2018). While the consequences of such steps have yet to completely reveal themselves, these trade policies have many in Asia concerned.

Any trade war between the US and China would have significant implications for all of Asia. As the region's largest trading partner, China is an important source of investment and tourism. Aggressive trade policy measures against China by the US would see undoubtedly see demand fall for most economies in the region. While that presents some obvious challenges for the region (DBS, 2018), the large domestic markets of Indonesia and the Philippines may provide some insulation for these economies however, countries like Singapore, Malaysia, South Korea, and Taiwan, which rely more heavily of the exports would potentially be worse off. Moreover, those manufacturing machine parts and components for communications equipment used in the production of items that China then sells to the US, would be particularly vulnerable (Wood, 2018). In addition to this, local steel producers may put pressure on their respective governments to launch an anti-dumping case at the World Trade Organization (WTO) Dispute Settlement Board. A recent United Nations Economic and Social Commission for Asia and the Pacific (UNESCAP) report has warned of reduced economic growth for major developing Asian countries may fall by as much as $1.2 \%$ if trade protectionism and global insecurity increase (UNESCAP, 2018). The ramifications of which would be felt throughout the region. Another study conducted by the China International Capital Corporation Hong Kong Securities Limited (CICC) (2017) estimated that a rise in US trade protectionism (based on the on the assumption that US import tariff would rise on average by 5 percent) would led to a reduction in China's economic growth by 0.07 percent, while at the same time boosting US economic growth by 0.12 percentage points, in addition, world economic growth would fall by more than 0.06 percent. However, a computable general equilibrium study (CGE) by Cheong and Tongzon (2018), showed that an increase in US import tariffs would result in economic losses for the USA and the relevant trading partner or region to which the import tariff increase is applied (see Table 1). Moreover, they also showed that an increase in US import tariffs for Chinese goods alone would not have any spillover effects on other East Asian countries. However, the inclusion of a border adjustment tax (BAT) for all countries and for all products would actually boost US economic growth (See Table 2) (Cheong and Tongzon, 2018).

Table 1. GDP effects of US tariff increases by 10 percent for all products Source: Cheong and Tongzon (2018)

\begin{tabular}{crrrr}
\hline Country & 2016 & 2021 & 2026 & -0.40 \\
US & -0.22 & -0.37 & 0.14 & 0.38 \\
China & -0.01 & 0.10 & 0.19 & 0.18 \\
Japan & 0.01 & 0.14 & 0.09 & 0.06 \\
South Korea & -0.01 & -0.07 & 0.11 & 0.08 \\
ASEAN & 0.01 & 0.10 & 0.16 & 0.16 \\
EU & 0.01 & 0.11 & 0.05 & -0.01 \\
Rest of the World & 0.02 & 0.07 &
\end{tabular}

Table 2. GDP effects of US tariff increase (10\%) and subsidy provision (10\%) for all products

\begin{tabular}{ccccc}
\hline Country & 2016 & 2021 & 2026 & 2031 \\
\hline US & -0.05 & 0.54 & 0.92 & -0.04 \\
China & 0.02 & 0.05 & 0.02 & 0.02 \\
Japan & 0.01 & 0.06 & 0.04 & -0.03 \\
South Korea & 0.03 & 0.07 & 0.05 & -0.02 \\
ASEAN & 0.02 & 0.08 & 0.09 & 0.07 \\
EU & 0.01 & 0.08 & 0.06 & -0.01 \\
Rest of the World & 0.01 & 0.08 & & \\
\hline
\end{tabular}


The export reduction impact of US trade protectionism of US trade protectionism on various Asian economies, depends on how significant the US market is to their exports. As Table 3 shows, there are significant variations in the level of merchandise exports between the US and its Asian trading partners. Countries like China, Japan, South Korea, the Philippines and Thailand, are more likely going to be effected by neo-protectionist trade policy measures as the US market consists of $17-20 \%$ of their merchandise exports.

Table 3. Exports of East Asia to the US (Billion \$US) Source: http://unctastat.unctad.org (UNCTAD)

\begin{tabular}{ccc}
\hline Trading partner & Value (Billions of USD \$) & Share (\%) \\
\hline China & 457 & 20 \\
Indonesia & 20 & 13 \\
Japan & 128 & 20 \\
Malaysia & 32.5 & 16 \\
Philippines & 10.2 & 17 \\
Singapore & 16.5 & 5 \\
South Korea & 72.7 & 14 \\
Thailand & 28.6 & 13 \\
\hline
\end{tabular}

Driving these potential impacts on the Asian region have been changes in US trade policy formation. Historically, the trade policy decision making body was the President and the Congress. However, since President Trump took office, he has exercised his power through by using Executive Orders and Presidential Memoranda on international trade issues. Meanwhile, the use of Congressional power for trade issues has reduced. Further, President Trump has established a new position titled the Office of Trade, Manufacturing Policy (OTMP). These examples highlight how the institutional trade negotiating bodies have been reshaped and as such affect the trade negotiations with major trading partners in the Asian region.

Meanwhile in other parts of Asia, the renegotiation of the Korea-US (KORUS) FTA by the Trump administration in South Korea concerned about what any final outcome may bring. At the center of the discussion are concerns over the growing deficit between the US and Korea. Completed under President George W. Bush and partially renegotiated by President Barack Obama, the deal came into effect in 2012. However, in an April 2017 interview with the Washington Post, President Trump stated that he might withdraw the US from the deal if negotiations to update it fail. Since then, trade negotiators from the US and Korean have met to address possible areas for updating the deal to better suit their respective needs. In recent meetings, the issue of tariffs has been a pressing issue, with a March 2018 announcement by the US that it would be imposing a 25 percent tariff on imported steel and a 10 percent tariff on imported aluminum, due to take effect on Friday 23 March (ICTSD, 2018b). These measures come following a Commerce Department investigation as to whether imported steel and aluminum had posed national security risks to the US, from either a national defense or critical infrastructure perspective. Beyond Korea these measures prompted swift reactions from many of the US's key trading partners, as well as from the head of the World Trade Organization. Central to their argument were fears that these tariffs could upend global markets, complicate production processes, and spark retaliatory actions that could spiral quickly out of hand, the likes of which have occurred with China. However, despite such concerns, the US and Korea were able to sign the amended KORUS FTA on September 24, 2018. Key aspects from the renegotiated deal meant that Korea was now able to phase out the 25\% tariff on trucks until 2041 (which had originally been set for 2021), while Korea had also agreed to double the number of U.S. automobile exports to 50,000 cars per manufacturer per year that can meet U.S. safety standards (KPMG, 2018).

Despite the potential fears surrounding these US trade policy initiatives, there are still potential upsides. As the trade war is largely bilateral in nature, there could be some degree of trade diversion, which as a consequence may help many South East Asian economies (DBS, 2018). Moreover, recent trade gains have helped to establish a sufficient safety net for most Asian economies, particularly those heavily involved in commodity exports such as Thailand and Indonesia, which should insulate them against most shocks (OECD, 2017). There is also evidence to suggest that companies are looking to implement measures that seek to overcome some of the US trade policies currently being carried out in Asia. An HSBC study, surveyed the views of some 6,000 businesses, found that while firms believed governments were becoming more protective of their domestic economies, the majority of businesses in Asia were looking to regional partners to further develop trade opportunities (Wood, 2018). Beijing's new 25\% tariff on American soybeans could create new opportunities for Argentinean and Brazilian exporters of the product. Moreover, the ramifications of increased tariffs on US agricultural products entering China could make it easier for countries like Thailand to export their fresh and processed fruits to China. While tariffs on steel and aluminum imported to the US could benefit other significant buyers of the metal in Asia, such as the Philippines. 
Reshaping Institutional Arrangements for the Trade Policies of the US and their Implications for the Asian Region

Table 4. US merchandise trade with China FTA partner countries, 2001-2015 (Billion \$US)

Source: U.S. Census Bureau

\begin{tabular}{|c|c|c|c|c|c|c|c|c|c|c|c|c|c|c|c|}
\hline Countries & 2001 & 2002 & 2003 & 2004 & 2005 & 2006 & 2007 & 2008 & 2009 & 2010 & 2011 & 2012 & 2013 & 2014 & 2015 \\
\hline $\begin{array}{l}\text { Total all } \\
\text { countries }\end{array}$ & -427.2 & -482.9 & -547.6 & -665.4 & -782.7 & -838.3 & -794.5 & -816.2 & -503.6 & -634.9 & -727.4 & -729.6 & -702.2 & -752.2 & -762.6 \\
\hline $\begin{array}{l}\text { Total FTA } \\
\text { countries }\end{array}$ & -97.0 & -99.9 & -108.2 & -132.4 & -144.9 & -146.7 & -140.4 & -126.6 & -61.9 & -79.0 & -80.5 & -70.5 & -67.6 & -66.9 & -64.0 \\
\hline China & -83.1 & -103 & -124 & -162.3 & -202.3 & -234.1 & -258.5 & -268 & -226.9 & -273 & -295.2 & -315.1 & -318.7 & -344.8 & -367.3 \\
\hline Israel & -4.5 & -5.4 & -5.9 & -5.4 & -7.1 & -8.2 & -7.8 & -7.8 & -9.2 & -9.7 & -9.1 & -7.9 & -9.0 & -7.9 & -10.9 \\
\hline NAFTA & -82.9 & -85.3 & -92.3 & -111.5 & -128.2 & -136.1 & -142.8 & -143.1 & -69.4 & -95.0 & -98.9 & -93.0 & -86.4 & -81.9 & -76.2 \\
\hline Canada & -52.8 & -48.2 & -51.7 & -66.5 & -78.5 & -71.8 & -68.2 & -78.3 & -21.6 & -28.5 & -34.5 & -31.4 & -31.7 & -36.5 & -15.5 \\
\hline Mexico & -30.0 & -37.1 & -40.6 & -45.1 & -49.7 & -64.3 & -74.6 & -64.7 & -47.8 & -66.4 & -64.5 & -61.6 & -54.6 & -55.4 & -60.7 \\
\hline Jordan & 0.1 & 0.0 & -0.2 & -0.5 & -0.6 & -0.8 & -0.5 & -0.2 & 0.3 & 0.2 & 0.4 & 0.6 & 0.9 & 0.6 & -0.1 \\
\hline Australia & 4.5 & 6.6 & 6.7 & 6.7 & 8.5 & 9.6 & 10.6 & 11.6 & 11.6 & 13.2 & 17.3 & 21.6 & 16.9 & 16.0 & 14.1 \\
\hline Chile & -0.4 & -1.2 & -1.0 & -1.1 & -1.4 & -2.8 & -0.7 & 3.7 & 3.4 & 3.9 & 6.9 & 9.4 & 7.1 & 7.1 & 6.7 \\
\hline Singapore & 2.7 & 1.4 & 1.4 & 4.2 & 5.5 & 6.9 & 7.9 & 12.0 & 6.5 & 11.6 & 12.1 & 10.3 & 12.8 & 13.6 & 10.2 \\
\hline CAFTA-DR & -1.9 & -1.9 & -1.8 & -1.9 & -1.2 & 1.0 & 3.7 & 6.0 & 1.1 & 0.6 & 1.5 & -1.0 & -0.5 & 2.7 & 5.0 \\
\hline Costa Rica & -0.4 & 0.0 & 0.0 & 0.0 & 0.2 & 0.3 & 0.6 & 1.7 & -0.9 & -3.5 & -4.1 & -4.8 & -4.7 & -2.6 & 1.6 \\
\hline Dom. Rep. & 0.2 & 0.1 & -0.2 & -0.2 & 0.1 & 0.8 & 1.9 & 2.6 & 1.9 & 2.9 & 3.1 & 2.6 & 2.9 & 3.4 & 2.5 \\
\hline El Salvador & -0.1 & -0.3 & -0.2 & -0.2 & -0.1 & 0.3 & 0.3 & 0.2 & 0.2 & 0.2 & 0.9 & 0.5 & 0.8 & 0.9 & 0.7 \\
\hline Guatemala & -0.7 & -0.8 & -0.7 & -0.6 & -0.3 & 0.4 & 1.0 & 1.3 & 0.7 & 1.3 & 1.4 & 1.3 & 1.4 & 1.7 & 1.7 \\
\hline Honduras & -0.7 & -0.7 & -0.5 & -0.6 & -0.5 & 0.0 & 0.5 & 0.8 & 0.0 & 0.7 & 1.6 & 1.1 & 0.9 & 1.3 & 0.5 \\
\hline Nicaragua & -0.2 & -0.2 & -0.3 & -0.4 & -0.6 & -0.8 & -0.7 & -0.6 & -0.9 & -1.0 & -1.5 & -1.6 & -1.7 & -2.1 & -1.9 \\
\hline Morocco & -0.2 & 0.2 & 0.1 & 0.0 & 0.1 & 0.4 & 0.7 & 0.6 & 1.2 & 1.3 & 1.8 & 1.2 & 1.5 & 1.1 & 0.6 \\
\hline Bahrain & 0.0 & 0.0 & 0.1 & -0.1 & -0.1 & -0.2 & 0.0 & 0.3 & 0.2 & 0.8 & 0.7 & 0.5 & 0.4 & 0.1 & 0.4 \\
\hline Oman & -0.1 & 0.0 & -0.4 & -0.1 & 0.0 & -0.1 & 0.0 & 0.5 & 0.2 & 0.3 & -0.8 & 0.4 & 0.5 & 1.0 & 1.4 \\
\hline Peru & -0.3 & -0.4 & -0.7 & -1.6 & -2.8 & -3.0 & -1.2 & 0.4 & 0.7 & 1.7 & 1.7 & 2.9 & 2.0 & 4.0 & 3.7 \\
\hline Colombia & -2.1 & -2.0 & -2.6 & -2.8 & -3.4 & -2.6 & -0.9 & -1.7 & -1.9 & -3.6 & -8.8 & -8.3 & -3.3 & 1.8 & 2.2 \\
\hline Panama & 1.0 & 1.1 & 1.5 & 1.5 & 1.8 & 2.3 & 3.4 & 4.5 & 4.0 & 5.7 & 7.9 & 9.3 & 10.1 & 10.0 & 7.3 \\
\hline South Korea & -13.0 & -13.0 & -13.2 & -19.8 & -16.0 & -13.4 & -12.9 & -13.4 & -10.6 & -10.0 & -13.2 & -16.6 & -20.7 & -25.1 & -28.3 \\
\hline $\begin{array}{l}\text { Total FTA } \\
(\% \text { share })\end{array}$ & $22.7 \%$ & $20.7 \%$ & $19.8 \%$ & $21.5 \%$ & $18.5 \%$ & $17.5 \%$ & $17.7 \%$ & $15.5 \%$ & $12.3 \%$ & $12.4 \%$ & $11.1 \%$ & $9.7 \%$ & $9.6 \%$ & $8.9 \%$ & $8.4 \%$ \\
\hline
\end{tabular}




\section{Conclusion}

Over the course of the last 100 years, US trade policy has emerged from the depths of ardent protectionism to a passionate supporter of free trade. At the heart of this underlying foundation has been a strong desire to not only abolish unfair and protectionist trade barriers but also reduce tariff levels in a manner that expands the parameters of the global economy. Growth that has also led to improvements in environmental and labor standards and employment opportunities for millions of people around the world. However, in recent times President Trump has sought to engage in more protectionist trade policy measures. In this instance, trade initiatives have focused on overcoming the threat of Chinese economic domination.

A key part of this new neo-protectionist agenda has been an intense desire to promote US industry through the slogan "Made in America" and efforts to "Make America Great Again". These efforts are a clear indication of the government's ambition to help a struggling middle class by helping to foster job growth at home. Under US President, Donald Trump, America appears destined to change key international trade policy provisions, particularly with respect to China. America has also changed key international trade policy provisions by stepping back from its role a leader of free trade, abandoning the TPP, and launching into a tit-for-tat battle of tariff hikes with China. All of which are far removed from its traditional trade policy beliefs. With the WTO, Doha Agenda and other multilateral settings proving unsuccessful these days, many countries, including Korea, as well as those still involved in completing the TPP, face an uncertain trade negotiation future. In the wake of these concerns a new era of protectionism may just be around the corner.

A return to the beggar-thy-neighbor policies of the 1930s may see other countries around the world following suit. The Brexit decision is already an indication that winds of change are in the midst. This new anti-globalization theme could have dire consequences for export dependent countries like Korea and the global economy as a whole (Wood and Jang, 2017). As such, it is imperative that governments respond by investing in research and development activities, encouraging foreign investment opportunities in a manner that provides a solution to possible future import regulations. In Korea, the changing dynamics of the international trade landscape have also brought about changes to the way that policy decisions are made. This has meant that in recent years, the Korean National Assembly has taken on a more significant role in the formation of trade policy as we have seen in the U.S. Congress. In particular, immediately following the ratification of the Korea-US FTA, the Korean National Assembly enacted a new law on the conclusion procedures and implementation of commercial treaties. The law requires the Ministry of Trade, Industry and Energy (MOTIE) to hold a public hearing before concluding a commerce treaty (Article 7), to assess the economic feasibility of a commerce treaty before entering the negotiations (Article 9), and also to submit various reports to the Korean National Assembly on the ongoing commercial negotiations, commerce treaties to be signed, and the main terms of the treaty when it was signed (Articles 5 and 12). In addition to this, the Minister of Trade role has been re-established and is responsible for the management of all international trade issues within the MOTIE. Unlike the US, Korea has no USTR or other similar agencies that are solely responsible for trade negotiations, and are independent of industry and trade matters, while policy offerings such as Trade Adjustment Assistance (TAA) are also fundamentally different (Pyo et al., 2016). In Korea, the task of international trade was once the responsibility of the Bureau of International Trade Negotiations which came under the Ministry of Foreign Affairs. However, during this new era of neo-protectionism, the Korean Government recognized the importance of trade issues by re-establishing the Minister of International Trade position within the MOTIE. Among others, an important role of the Minister of Trade is to effectively connect trade related issues with commerce and industry, as well as forming more effective communication channels with the National Assembly. Furthermore, a new position of Secretary to the President on International Trade was also established in the Korea Blue House (The Office of President) for the purpose of playing a coordination role between the President Office and relevant ministries.

\section{References}

Cheong, I., Tongzon, J., 2018. The economic impact of a rise in US trade protectionism on East Asia. Journal of Korea Trade 22, 265279.

China International Capital Corporation Hong Kong Securities Limited (CICC), 2017. Impacts of Trade Protectionism on US and Chinese Economies, Macroeconomic Research. China International Capital Corporation Hong Kong Securities Limited (CICC), January 9

Cimino-Isaacs, C.D., 2018. U.S. trade policy primer: Frequently asked questions. Congressional Research Service. R45148.

DBS, 2018. Singapore: Opportunity from the Trade War. DBS Group Research Report.

Fergusson, I.F., 2015. Trade Promotion Authority (TPA) and the Role of Congress in Trade Policy. Congressional Research Service. July 2015.

Froman, M., 2014. The strategic logic of trade: New rules of the road for the global market. Foreign Affairs 6, 111-118.

Froman, M., 2015. Written Statement on Senate Committee on Finance, January 27, 2015.

Garriaga, A.C., 2009. Regime type and bilateral treaty formation: Do too many cooks spoil the soup?. The Journal of Conflict Resolution 53, 698-726.

Hornbeck, J.F., 2013. Trade adjustment assistance (TAA) and its role in U.S. trade policy. Congressional Research Service 7-5700

International Centre for Trade and Sustainable Development (ICTSD), 2018a. US President Signs Memo on Proposed Section 301 Measures Directed at China, Bridges 22. 
International Centre for Trade and Sustainable Development (ICTSD), 2018b. Specter of US Steel, Aluminum Tariffs Draws Scrutiny from International Trade Community, Bridges, 22.

Kim, D.S., 2006. Foreign Trade Policy Goals and Strategies of the United States, Policy 2006-61. Gyeonggi Research Institute, Korea. Klynveld Peat Marwick Goerdeler (KPMG), 2018. United States-Korea free trade agreement, negotiation outcomes, KPMG. <https://h ome.kpmg.com/xx/en/home/insights/2018/09/tnf-us-korea-fta-negotiation-outcomes.html>.

Ko, H.C., Choi, H.R., 2014. Determinants of the US House of Representatives Trade Policies and Their Implications. Foreign Economic Policy Institute, a policy research briefing, Korean.

Lin, J.Y., Wang, X., 2018. Trump economics and China-US trade imbalances. Journal of Policy Modeling 40, 579-600.

Organization for Economic Co-operation and Development (OECD), 2017. Economic Outlook for Southeast Asia, China and India 2017, OECD. <https://www.oecd.org/dev/asia-pacific/SAEO2017_Overview_11-01-2017_PDF_HD_web.pdf>.

Petri, P.A., Plummer, M.G., 2016. The economic effects of the trans-pacific partnership: new estimates. Peterson Institute for International Economics, Working Paper 16-2.

Pyo, I., Wood, J., Kim, J., 2016. An evaluation of the Korean trade adjustment assistance (TAA) program. Journal of International Logistics and Trade 14, 219-229.

Schmidt, A.R., 2009. A new trade policy for America: Do labor and environmental provisions in trade agreements serve social interests or special interests. Indiana International and Comparative Law Review 19, 167-201.

Stiglitz, J., 2018. Trump and globalization, Journal of Policy Modeling 40, 515-528.

United Nations Economic and Social Commission for Asia and the Pacific (UNESCAP), 2018. Economic and Social Survey for Asia and the Pacific, UNESCAP. 〈https://www.unescap.org/op-ed/economic-and-social-survey-asia-and-pacific-2018>.

United States Trade Representative (USTR), 2015. The President's Trade Agenda, America, Office of the USTR. <https://ustr.gov/trad e-agreements>.

United States Trade Representative (USTR), 2016. Interagency Role, Office of the USTR. <https://ustr.gov/about -us/interagencyrole>.

United States Trade Representative (USTR), 2018. USTR Issues Tariffs on Chinese Products in Response to Unfair Trade Practices, Office of the USTR. <https://ustr.gov/about-us/policy-offices/press-office/press-releases/2018/june/ustr-issues-tariffs-chineseproducts>.

USITC, 2016. Trans-Pacific Partnership Agreement: Likely Impact on the U.S. Economy and on Specific Industry Sectors. United States International Trade Commission, May 2016 Publication Number: 4607 Investigation Number: TPA-105-001

Wood, J. 2018. The New Wave of Protectionist Trade Policy in Asia, Access Asia. Australian Chamber of Commerce, Singapore.

Wood, J., Jang, H., 2017. Brexit: The economic and political implications for Asia. Social Sciences 6, 1-11. 